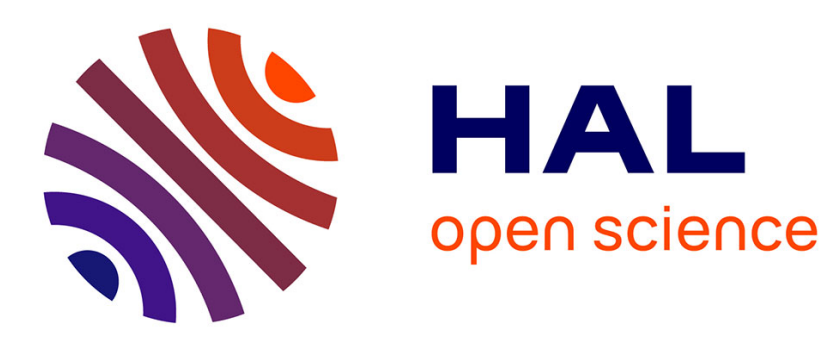

\title{
Clitic clusters in early Italo-Romance and the syntax/phonology interface \\ Diego Pescarini
}

\section{To cite this version:}

Diego Pescarini. Clitic clusters in early Italo-Romance and the syntax/phonology interface. Challenging Clitics, 2013. hal-01762663

\section{HAL Id: hal-01762663 \\ https://hal.science/hal-01762663}

Submitted on 11 Apr 2018

HAL is a multi-disciplinary open access archive for the deposit and dissemination of scientific research documents, whether they are published or not. The documents may come from teaching and research institutions in France or abroad, or from public or private research centers.
L'archive ouverte pluridisciplinaire HAL, est destinée au dépôt et à la diffusion de documents scientifiques de niveau recherche, publiés ou non, émanant des établissements d'enseignement et de recherche français ou étrangers, des laboratoires publics ou privés. 


\title{
Clitic clusters in early Italo-Romance and the syntax/phonology interface
}

\section{Diego Pescarini (University of Padua)}

\begin{abstract}
This paper deals with the morpho-phonology of Italo-Romance clitic clusters. It argues that morpho-phonological processes (i.e. apocope, prosthesis, etc.) are sensitive to both the syntactic make-up of clitic clusters and their prosodic structure. The first part of the paper aims to support the hypothesis that a clitic cluster is a Foot, daughter to a recursive Prosodic Word (Peperkamp 1995, 1996, 1997). The second part of the paper accounts for the distribution of the apocopated clitic $l(<l o$ 'it/him'/'the.m.sg') in early Italo-Romance. I show that the distribution of $l$ follows from syllabic constraints and alignment constraints compatible with the foot-based analysis. The last section addresses a puzzling vowel alternation which targets the leftmost clitic of certain clusters in Old and Modern Italian.
\end{abstract}

\section{Introduction}

Theories of prosodic hierarchies differ with respect to the status of clitics. Nespor and Vogel (1986:150), on the one hand, claim that clitics are unstressed Prosodic Words (PrW ${ }^{1}$ ) dominated by a Clitic Group (C), see (1a), while Selkirk (1995), on the other hand, argues that they are extrametrical syllables and daughters to a recursive PrW as shown in (1b).

a.

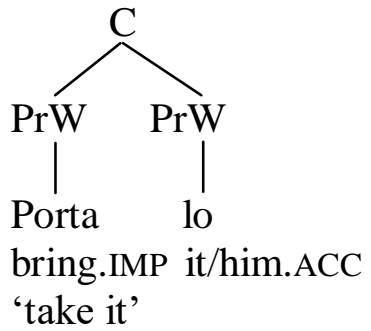

b.

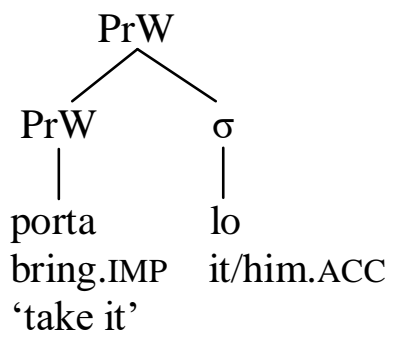

These approaches differ further in the analysis of clitic clusters, i.e. sequences of two or more clitic elements. According to Nespor \& Vogel (1986), a clitic cluster is a series of sister PrWs under the same C node (multiple branching is therefore allowed), as shown in (2a). On the contrary, scholars like Peperkamp (1995, 1996, 1997) and Monachesi (1996) have proposed that clusters correspond to an autonomous prosodic constituent. In particular, Peperkamp argues that clitic clusters are Feet and daughters to a recursive PrW as schematized in (2b).

(2)

a.

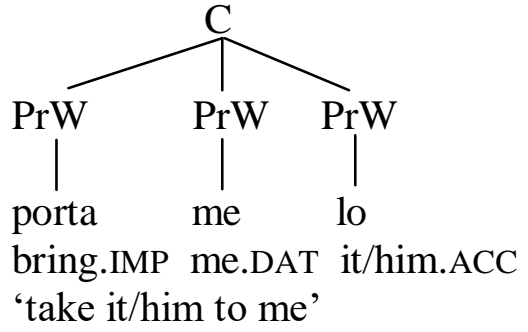

b.

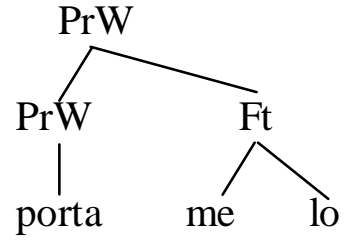

bring.IMP to.me it/him.ACC

'take it/him to me'

The above geometries show a major distinction between symmetric and asymmetric models. Symmetric representations - like (1a), (2a) - are based on the assumption that clitics and clitic clusters have the same prosodic category as their lexical host, and that prosodic

\footnotetext{
${ }^{1}$ In what follows I use the following abbreviations: $\mathrm{PPh}=$ Prosodic Phrase, $\mathrm{C}=$ Clitic Group, PrW $=$ Prosodic Word, $\mathrm{Ft}=$ Foot, $\sigma=$ syllable.
} 
structures are non-recursive and exhaustive (see below). Asymmetric approaches, on the contrary, entail that clitic elements are prosodically 'deficient,' in the sense that they do not correspond to a PrW, and, as a consequence, give rise to prosodic configurations like those in (1b), (2b), which violate basic principles of prosodic hierarchies such as nonrecursivity in (3) and exhaustivity in (4):

(3) Nonrecursivity: no Constituent ${ }^{\mathrm{i}}$ dominates Constituent $^{\mathrm{j}}$ if $_{\mathrm{j}}^{\mathrm{j}} \mathrm{i}$, e.g. no PrW dominates another PrW

(4) Exhaustivity: no Constituent ${ }^{i}$ dominates Constituent $^{j}$ if $j<\mathrm{i}-1$, e.g. no PrW directly dominates a syllable

In the following sections I address the distribution of some (morpho)phonological phenomena in various Romance languages, including medieval Italo- and Gallo-Romance, in order to show that asymmetric geometries like those in (1b) and (2b) do in fact account for the majority of the data.

The present work opens with a criticism of symmetric models like Nespor \& Vogel's (section 2): I argue that phenomena like phono-syntactic doubling (raddoppiamento fonosintattico), intervocalic $s$-voicing and apocope in modern Italian do not support the claim that clitics are unstressed PrWs and, consequently, that clitic clusters are sequences of PrWs. Rather, section 3 argues in favour of Peperkamp's claim that clitic clusters are Feet following Bafile's $(1992,1994)$ analysis of Neapolitan clusters and revising Horne's (1990) account of syncope in Old French.

In section 4, I turn to medieval vernaculars of northern Italy and, in particular, to the distribution of the apocopated clitic $l$ (from lo 'him/it'), which is summarized in (5). As Vanelli (1992/1998) pointed out, the apocopated element $l$ is found i. enclitically, as in (5a), unless it follows an infinitive, as in (5b); ii. after another clitic element, as in (5c-d). By contrast, lo does not undergo apocope when it is proclitic and follows another PrW, as in (5e). (For the sake of consistency, the following examples are taken from texts by the same author, writing in the vernacular spoken in Verona in the $13^{\text {th }} / 14^{\text {th }}$ century; see Pescarini 2011).

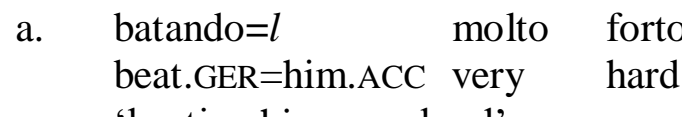

(Giacomino, Babilonia 83)

'beating him very hard'

b. per far $=l o \quad$ tosto cosro

for make.INF=him.ACC immediately cook.INF

(Giacomino, Babilonia 123)

'to have him cooked immediately'

c. voler $=v e=l \quad$ dir tuto

(Giacomino, Babilonia 89)

want. $\mathrm{INF}=$ you.DAT=it.ACC say all

'to want to say it all to you'

d. ve $=l$ poës cuitar

(Giacomino, Ierusalem 238)

you.PL.DAT=it.ACC can.3.SG tell.INF

'he can tell it to you'

e. en un' aqua lo meto

in a water him.ACC put.3.PL

(Giacomino, Babilonia 113) 
'they put him in some water'

Following the foot-based analysis illustrated in (2b), I show that the distribution of apocope results from syllabic and alignment constraints on the re-syllabification of $l$.

Lastly, section 5 addresses a puzzling vowel alternation found in Italian clusters: before a $3 p$ accusative clitic (e.g. lo 'him', la 'her') or the partitive ne ('of it/them'), clitics end with $-e$ instead of the expected $-i$. For instance, the clitic $m i$ '(to) me' becomes $m e$, see (6a), and the $3 \mathrm{p}$ m.sg clitic gli becomes glie / $\mathrm{ke/}$, see (6b).

$\begin{array}{lll}\text { a. } & {[\mathrm{me}] \text { lo porti }} & {\left[{ }^{*} \mathrm{mi}\right]} \\ & \text { me.DAT it.ACC bring.2SG } \\ & \text { 'You take it to me' } \\ \text { b. } & {[\text { Ke }] \text { ne porti due }} \\ & \text { him.DAT of.it bring.2SG two } \\ & \text { 'You bring him two of it' }\end{array}$

In the light of the previous discussion, I speculate on the nature of the -e/i-alternation and its correlation with foot-formation and alignment restrictions. I argue that, synchronically, the $e / i$ - alternation is not sensitive to secondary stress, but rather to syntactic edges.

\section{Against symmetry}

Nespor and Vogel (1986), Nespor (1990, 1993) argue for the analysis of clitics and clitic clusters schematized in (1a)-(2a) on the basis of data from modern Italian ${ }^{2}$. In particular, they focus on three phonological phenomena that, in their opinion, can be considered as constituency tests. Such processes, exemplified later on, are as follows:

i. $\quad$ intervocalic $s$-voicing, which targets word-internal sibilants in northern Italian;

ii. Raddoppiamento sintattico (syntactic doubling), which targets word-initial consonants in central-southern Italian;

iii. apocope (or troncamento, in Nespor's (1990, 1993) terms), which targets wordfinal vowels after single sonorants.

In what follows, I will argue that voicing and raddoppiamento are not proper diagnostics for the prosodic status of clitics, as they cannot discriminate between the models in (1a) and (1b). With respect to apocope, I will notice that in modern Italian this rule is grammaticalized, as it applies only within a specific morpho-syntactic context, namely infinitive + enclitic.

Intervocalic $s$-voicing is a peculiar feature of northern Italian, where intervocalic sibilants in word-internal position are voiced.

$$
\begin{aligned}
/ \text { la susanna/ } \rightarrow & \text { [la su'zan:a }] \quad \text { lit. 'the Susan' } \quad \text { (northern Italian) } \\
& * \text { la su'san:a }] \\
& * \text { la zu'zan:a }]
\end{aligned}
$$

However, voicing is blocked when /s/ is in morpheme-initial position, for instance, after prefixes like Italian $a$-, anti-, and between the members of a compound (Nespor \& Vogel 1986:124-129, Oostendorp 1999, Krämer 2009:207-219 and references therein):

\footnotetext{
${ }^{2}$ Part of Nespor \& Vogel's analysis is based on data from modern Greek. For the sake of consistency I will not address these data here.
} 


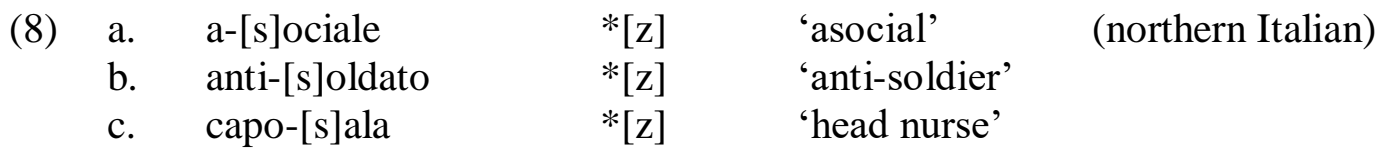

On the contrary, [s] usually undergoes voicing when it is in morpheme-final position ${ }^{3}$ :

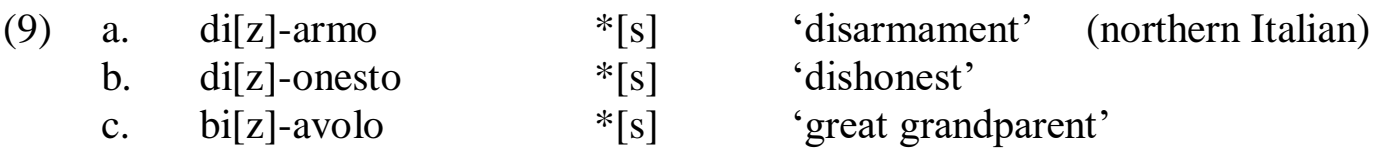

Despite these complications, Nespor \& Vogel adopt $s$-voicing as a word-hood test to show that clitics behave like PrWs. As a matter of fact, $s$-voicing is never found between a clitic and its host, as shown in (10):
$\begin{array}{lllll}\text { (10) } & \text { a. lo } & \text { [s]aluto } & \text { (northern Italian) }\end{array}$
him.ACC greet.1.SG
'(I) greet him'
b. essendo $=[\mathrm{s}] \mathrm{i} \quad$ salutati $*[\mathrm{z}]$
be.GER=each.other greet.PART
'having greeted each other'

Since voicing is blocked with both proclitics (11a) and enclitics (11b), they conclude that both the clitic pronoun and its lexical host are PrWs, as schematized in (1a), repeated below with modifications:<smiles>[AlH2]NC[GeH2]</smiles>

(northern Italian)

Furthermore, as voicing is not allowed also between clitics, see (12), they argue that each clitic corresponds to a separate PrW, as schematized in (2a), repeated below in (13) with modifications:
lo $\quad[\mathrm{s}] \mathrm{i}$ porta
it/him.ACC one brings
'one takes it'

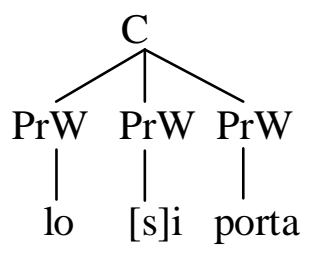

\footnotetext{
${ }^{3}$ One might object that the prefixed/compound words in (8) have been borrowed from standard Italian as nonadapted loanwords with an unvoiced pronunciation. However, northern dialects display native words with the same feature, e.g. the Veneto adjective desavio/desalio [desa'vio/ desa'lio] < DE SAPITUM 'without salt'.
} 
However, as previously mentioned, the absence of voicing within clitic+word and clitic+clitic sequences can be due to the general rule preventing voicing from taking place in morpheme-initial position, as in the case of prefixed words in (8). Hence, the distribution of voicing is not a reliable test to determine the nature of a prosodic boundary.

After s-voicing, Nespor \& Vogel turn their attention to a typical word-initial process found in central and southern Italian: raddoppiamento sintattico, i.e. consonant gemination after oxytone words or functional elements ending with an etymological consonant, e.g. the preposition $a$ 'at/to' < Lat. AD. The conditions triggering raddoppiamento are subject to cross-linguistic variation: most southern Italian varieties, for instance, do not display raddoppiamento after oxytones (see Loporcaro (1997a) among others), while Tuscan varieties, illustrated below, exhibit both phonologically-conditioned and lexicallyconditioned doubling.

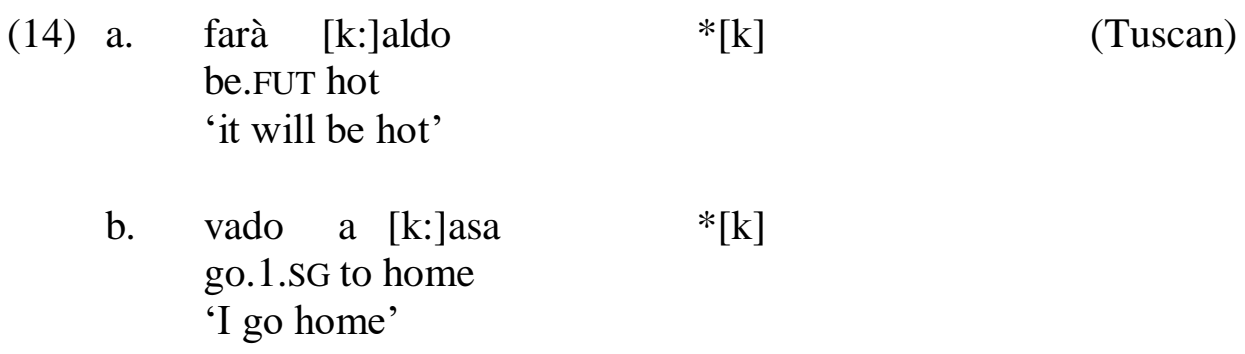

Also, enclitic elements are subject to raddoppiamento after oxytone verbs.
(15)
$\mathrm{da}=[\mathrm{m}:] \mathrm{i}$
'give me'
$*[\mathrm{~m}]$
(Italian)
give.IMP=me.DAT
b. $\quad$ amò=[1: ]o
$*[1]$
$\left(\right.$ Old Italian $\left.{ }^{4}\right)$
love.PAST.3.SG=him/it.ACC
'(he/she) loved him/it'

However, it is worth noting that, in sequences like (15), doubling is mandatory also in northern Italian, while the same variety does not allow the general raddoppiamento pattern in (14): this means that northern speakers have the context-specific rule responsible for (15), which I will refer to as 'enclitic gemination' although they lack the raddoppiamento rule.

A similar distinction between raddoppiamento and enclitic gemination can be found also in central and southern varieties, where raddoppiamento does not target a following proclitic element, as shown in (16b).
(16) a. a [r:]oma
$*[\mathrm{r}]$
(Abruzzese)
at/to Rome
'at/(to) Rome'
b. a [1]a casə
at/to the home
'(at) home'

\footnotetext{
${ }^{4}$ Modern Italian no longer allows enclitics after finite verbs.
} 
Enclitics, on the contrary, are doubled after imperatives:
fa [1:]ə
$*[1]$
(Abruzzese)
do it.ACC
'do it!'

Again, there is evidence that the rule causing enclitic gemination in (17) is not an instance of raddoppiamento, which, as shown in (16b), does not target clitic elements. Hence, raddoppiamento cannot be considered a robust test to confirm that clitics are PrWs as enclitics are doubled even in northern varieties, where raddoppiamento is not attested, and in southern varieties, where it does not target clitic elements.

To summarize, I have argued that the absence of $s$-voicing and enclitic gemination do not prove that a clitic and its host are separated by a PrW boundary: we have seen that $s$-voicing is blocked whenever it is preceded by a morphological boundary, while enclitic gemination has nothing to do with the word-initial rule of raddoppiamento sintattico ${ }^{5}$.

We can now turn to the third phenomenon analysed by Nespor \& Vogel, i.e. apocope, which in modern Italian is found only with infinitives when followed by a clitic element, like in (18), or by another infinitive, like in (19); cf. Cardinaletti \& Shlonsky (2004) for a syntactic analysis.

$$
\begin{aligned}
& \text { portar }(* \mathrm{e})=\mathrm{lo} \\
& \text { bring.INF=it.ACC } \\
& \text { 'to take it' } \\
& \text { Lo voglio far }(* \mathrm{e}) \text { portare } \\
& \text { It/him. ACC want.1.SG make.INF bring.INF } \\
& \text { 'I want make somebody take it/him' }
\end{aligned}
$$

According to Nespor (1990, 1993), the pattern in (18) depends on a phonological rule having the clitic group as its prosodic domain. Monachesi (1996:55) and Peperkamp (1996:109), however, point out that apocope is not allowed when the enclitic pronoun follows finite verbal forms, like in (20a), although the same verbal form allows apocope when it is not followed by an enclitic pronoun, as in (20b):
(20) a

$$
\begin{aligned}
& \text { facciam*(o)=lo veloci } \\
& \text { do.1PL=it.ACC quick } \\
& \text { 'let's do it quickly' }
\end{aligned}
$$
b. facciam(o) veloci
do.1PL quick
'let's do (it) quickly'

\footnotetext{
${ }^{5}$ It seems to me that, even leaving these objections aside, Nespor \& Vogel's conclusion is logically flawed. Let us assume for the sake of argument that $s$-voicing and raddoppiamento are reliable tests showing that a fullyfledged PrW boundary intervenes between the clitic and the preceding/following word. Following this (wrong) conclusion, one would argue that the PrW boundary blocks word-internal processes (like $s$-voicing) and triggers word-initial ones (like raddoppiamento). However, while a PrW boundary entails that at least one element (either the preceding or the following one) is a PrW, it does not mean that both elements - namely, the clitic and its host - are PrWs. The latter is a theoretical assumption which is logically faulty. In fact, the same patterns can be easily accounted for on the basis of both (1a) and (1b), as in both the clitic is preceded by a PrW boundary, even if the clitic itself has a different prosodic status.
} 
On the basis of these data, we can therefore object that in modern Italian, apocope cannot be treated as a pure phonological rule, as it is nowadays constrained within a specific morphosyntactic environment. As a consequence, a phonological account of apocope in modern Italian ends up being misleading, as the conditions responsible for apocope are ultimately morpho-syntactic in nature, rather than phonological. In early Italian and Italian vernaculars, on the contrary, apocope turns out to be rather productive and, consequently, more appealing for a prosodic analysis. I address this point in depth in section 4, after introducing clitic clusters.

\section{Clusters}

Symmetric and asymmetric approaches diverge further when clitic clusters are taken into consideration. According to Nespor \& Vogel (1986), clitic clusters - i.e. sequences formed by two or more clitic elements - can be represented as a series of sister PrWs under the same $\mathrm{C}$ node, as shown in $(2 \mathrm{a})=(21 \mathrm{a})$. Under Peperkamp's account, on the contrary, clusters correspond to Feet $(2 b)=(21 b)$.

a.

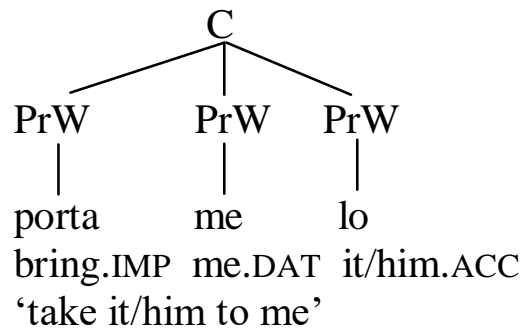

b.

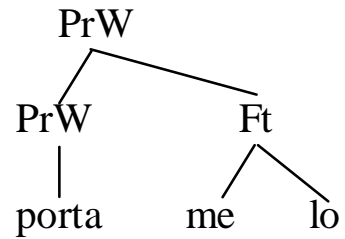

bring.IMP to.me it/him.ACC

'take it/him to me'

The latter model accounts straightforwardly for languages in which enclitic clusters are stressed. For instance, Bafile $(1992,1994)$ noticed that in Neapolitan, the penultimate pronoun of an enclitic cluster is stressed, as in (22b), while the same cluster in proclitic position is unstressed, cf. (23b):

(22) a

Pòrta=tə na bbirrə
bring.IMP=you.REFL.DAT a beer
'bring a beer for youself'

b.
pòrta $=t e ́=n n ə$
assaj
bring.IMP $=$ you.REFL.DAT=of.it a.lot.of
'bring a lot of it (beer) for youself'

(23)
you.REFL.DAT bring.PRES.1SG a beer
'I'll bring you a beer'
b. to
nə pòrtə
assaj
you.REFL.DAT of.it bring.PRES.1SG a.lot.of
'I'll bring you a lot of it (beer)'
single proclitic
proclitic cluster

single enclitic (Neapolitan)

enclitic cluster

According to Bafile's $(1992,1994)$ description, when stress is assigned to the penultimate clitic, the original stress of the lexical word continues to be primary (the $o$ in porto is open, and open mid vowels in Neapolitan are allowed only in syllables with primary stress). 
Furthermore, as a consequence of stress assignment, the inner enclitic is subject to metaphony (which typically affects primary stressed vowels): even if final vowels are reduced to $-\partial$, the underlying ending of the rightmost clitic triggers metaphony of the preceding element, whose vowel becomes $-i$ - if the following accusative clitic is masculine, and $-e$ - if it is feminine:

$$
\text { pòrta }=t i=l l ə
$$

bring.IMP=you.REFL.DAT=him.ACC/them.M.ACC/it.M.ACC

(Neapolitan)

'bring him/it.m/them for you'

b. $\quad$ pòrta $=t e=l l$ b

bring.IMP=you $\cdot$ REFL.DAT=her.ACC/them.F.ACC/it.F.ACC

'bring her/it.f/them.f for you'

According to Peperkamp (1995, 1996, 1997), the above pattern results from a prosodic configuration in which enclitic clusters are grouped under a metrical foot, as shown in (25b), while single enclitics, in (25a), behave like extrametrical syllables:

$$
\begin{aligned}
& \text { a. } \left.\quad[\text { pòrta }]_{\mathrm{PrW}} \text { to }\right]_{\mathrm{PrW}} \\
& \text { bring.IMP you.REFL.DAT } \\
& \text { 'Bring ... for yourself' } \\
& \text { b. } \left.[\text { [pòrta }]_{\mathrm{PrW}} \text { (té } \quad \text {.nnə) }\right]_{\mathrm{PrW}} \\
& \text { bring.IMP you.REFL.DAT of-it } \\
& \text { 'bring some of it for yourself' }
\end{aligned}
$$

(Neapolitan)

The resulting stress pattern - represented in (26) - entails that, in Neapolitan, stress is assigned cyclically, i.e. once the inner PrW has received stress, the outer PrW is subject to a second cycle, assigning stress to the penultimate clitic, i.e. to the foot's head (from now on, Ft/secondary stress is marked by a single asterisk; PrW/primary stress by two asterisks).

$\begin{array}{ll}* & * \\ * & *\end{array}$

$$
\left[[\text { (por.ta) }]_{\operatorname{PrW}}(\text { te } . n n \ni)\right]_{\operatorname{PrW}}
$$

Proclitic elements, on the contrary, are never stressed ${ }^{6}$. This, however, does not entail that foot formation does not take place proclitically. It only means that, in Neapolitan, proclitic foot-formation is not self-evident.

Evidence for foot formation in proclisis, however, is provided by Old French (Horne $1990^{7}$ ), which exhibits two processes targeting unstressed vowels:

\footnotetext{
${ }^{6}$ Rather, they are subject to processes of aphaeresis and elision, reducing clitic clusters to a single syllable (see Bafile 2008, 2012):

(i) Ite la porto/ $\rightarrow \quad$ [ta 'portə] you.REFL.DAT it.F.ACC bring.PRES.1SG 'I'll bring it to you'

(Neapolitan)

${ }^{7}$ Horne's analysis is couched in Nespor \& Vogel's (1986) framework. However, it seems to me that the French data are most consistent with the alternative analysis proposed by Peperkamp and supported here. In particular, Selkirk's recursive representation of clitics adopted by Peperkamp accounts straightforwardly for cases in which a lexical rule - like apocope and syncope - is extended to a postlexical domain like clitic + host sequences.
} 
i. $\quad$ apocope, deleting final vowels with the exception of $a$ (which become ə);

ii. syncope, deleting unstressed vowels when they follow a syllable bearing secondary stress.

The syncope rule can be represented as follows:

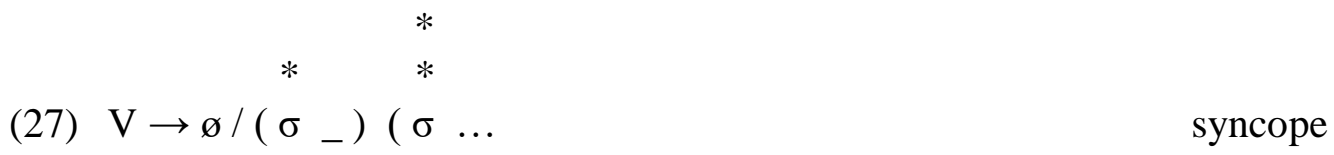

For instance, in case of a word like BONITATE(M), apocope and syncope apply as follows:

(28) $\left[(\text { bo.ni) }(\text { ta.te })]_{\mathrm{PrW}} \quad>\quad\right.$ /bon'te/ $\quad$ (Latin $>$ French)

With this in mind, let us turn to clitic clusters, which, in Old French, are subject to a rule deleting the final vowel of the cluster, as illustrated in (29).

(29) $\mathrm{Ne} \mathrm{m}(\mathrm{e})$ vidrent

(Old French)

NEG me.ACC see.PAST.3PL

'they did not see me'

In the light of the rule in (27), the pattern in (29) receives a straightforward explanation if one assumes - à la Peperkamp - that proclitic clusters are left-headed feet:

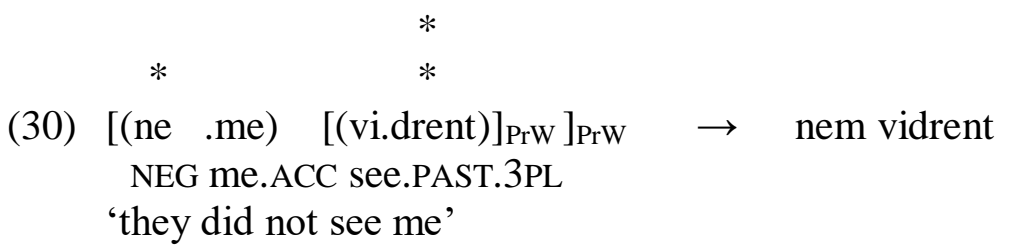

In conclusion, the data above confirm the hypothesis that clusters are feet rather than separate PrWs. Furthermore, the phenomena above also challenge Monachesi's (1996) claim that clusters are PrWs. If this were the case, we would not expect any asymmetry between proclitic and enclitic clusters in terms of stress and syncope, contrary to fact.

\section{Apocope in Early Italo-Romance}

Medieval northern vernaculars (including Old Florentine) share a 'core' rule of apocope, by which word-final $-o /-e$ are dropped after a single sonorant ${ }^{8}$; see (31).

\footnotetext{
${ }^{8}$ It is worth noting that apocope cannot be considered a merely phonological process since in many cases it is sensitive to the morpho-syntactic nature of the final vowel: for instance, if $-e$ is a feminine plural ending, as in the examples in (i), it never undergoes apocope, while apocope can take place if $-e$ derives from the thematic vowel of the Latin $3^{\text {rd }}$ declension, as in (ii).
}
(i) a. suor*(e)
'nuns'
b. $\operatorname{suol}^{*}(\mathrm{e}) \quad$ 'soles'
c. le pentol-on*(e) 'the big pots'
the.F.PL pot-SUFF 


$$
\left.[-\mathrm{o} /-\mathrm{e}] \rightarrow \varnothing /[+ \text { sonorant }]_{-}\right]_{\mathrm{PrW}}
$$

In the $13^{\text {th }} / 14^{\text {th }}$ century this rule is optional and subject to intra- and inter-linguistic variation, which I will address later on: for instance, it was active in old Italian, in which apocope was allowed, while it is no longer active in modern Italian, in which apocopated forms sound archaic and can be used only in a poetic register ${ }^{9}$.

Apocope also targets the $-o$ of the clitic element lo (< ILLUM), which expresses both the m.sg definite article and the m.sg object pronoun. In this case, however, apocope may be blocked by several phonological factors constraining the re-syllabification of the resulting clitic $l$. The following subsections address these constraints on the basis of data from Early Italo-Romance. In particular, I will focus on northern vernaculars, in which the distribution of the apocopated form $l$ is much more restricted than in Tuscan varieties.

As Vanelli (1992, 1998:179-185) pointed out, the distribution of apocope among northern vernaculars is consistent with the following diachronic evolution:

i. $\quad$ Stage 1: apocope is allowed only after another clitic element;

ii. $\quad$ Stage 2: apocope is allowed after every monosyllabic function word;

iii. Stage 3: apocope is allowed everywhere.

In the light of Selkirk's prosodic theory, we might assume that in Stage 1, apocope is allowed when $l o$ follows another "affixal clitic", i.e. a function word located within the same recursive PrW, which effectively means another clitic pronoun or a preposition:

$$
\left[[\mathrm{X} . l(o)]_{\mathrm{Ft}} \operatorname{PrW}\right]_{\mathrm{PrW}}
$$

(Stage1)

Later on (Stage 2), we can hypothesize that apocope is allowed when lo follows what Selkirk calls a "free clitic," namely, a function word sister to PrW and daughter to the Phonological Phrase (PPh), e.g. complementizers and conjunctions.

$$
\left[\mathrm{X}[l(o) \mathrm{PrW}]_{\mathrm{PrW}}\right]_{\mathrm{PPh}}
$$

Lastly, in Stage 3, apocope is allowed also after another PrW, which might be daughter to another PPh:

$$
[\mathrm{PrW}]_{\mathrm{PPh}}\left[[l(o) \operatorname{PrW}]_{\mathrm{PrW}}\right]_{\mathrm{PPh}}
$$

Old Florentine, for instance, is representative of Stage 3 as the allomorphs $l o$ and $l$ are in fact in free variation since the earliest attestations ${ }^{10}$.

\begin{tabular}{lll}
\hline (ii) a. & cuor(e) & 'hearth' \\
b. & sol(e) & 'sun' \\
c. & il pentol-on(e) & 'the big pot' \\
& the.M.SG pot-SUFF &
\end{tabular}

As the rule can discriminate between different kinds of inflectional endings, it means that the rule of apocope, even in Early Italo-romance, has a morpho-phonological nature.

${ }^{9}$ Although apocopated forms are perceived as archaic or poetic, Benincà (2008:74-76) noticed that speakers are still aware of the distribution of the rule and are therefore able to provide acceptability judgments on truncated forms: they must therefore have an implicit/passive competence of the constraints targeting this rule.

${ }^{10}$ Modern Italian exhibits a further evolution, as the allomorphs $l o / l$ ' (plus the epenthetic one, il, see below) alternate on the basis of the phonological context, but, synchronically, this alternation does not result directly from the aforementioned rule of apocope. 


\subsection{Syllabic constraints}

In general, apocope is blocked if the preceding sonorant follows another consonant (e.g. $\operatorname{incontr}^{*}(o)$ 'meeting') or if it is geminate ${ }^{11}$ (e.g. $\operatorname{torr}^{*}(e)$ 'tower'). Such a restriction follows from a more general principle preventing the formation of complex codas.

Post-lexically, the same restriction prevents the clitic lo from undergoing apocope after a word ending with a consonant. On the contrary, $-o$ can be dropped if the clitic follows a word ending with a vowel, as shown in the examples below, from various medieval vernaculars:
a. credendo $=l \quad$ tener
believe.GER=it.ACC keep.INF
'believing to keep it'
b. batando $=l \quad$ molto forto
beating.GER=him. ACC very hard
'beating him very hard'
c. farò=l se
do.FUT.1SG=it.ACC if...
'I will do it if...'
(Old Aretino, Guittone, Rime, p.109:40)
(Old Veronese, Giacomino, Bab., 83)

Things are more complicated when the enclitic lo follows an infinitive. In this case, both elements - namely, the clitic and the preceding verb - are candidates for apocope since they end with a sonorant followed by a thematic vowel. Therefore, a sequence formed by an infinitive, e.g. fare 'to make' and lo 'it/him,' could display three logically possible patterns of apocope:

$\begin{array}{llll}\text { (36) } & \text { a. } & \text { far(e) } & \text { lo } \\ \text { b. } & \text { fare } & 1(\mathrm{o}) \\ \text { c. } & \text { far(e) } & 1(\mathrm{o}) \\ & & \text { do.INF } & \text { it/him.ACC } \\ & & \text { 'to do it/him' }\end{array}$

apocope of the infinitive apocope of the clitic

apocope of both

In fact, only the pattern in (36a) is attested, as illustrated in (37):

$$
\begin{aligned}
& \text { per far-lo tosto cosro } \quad \text { (Giacomino, Babilonia 123) } \\
& \text { for make.INF=him.ACC immediately cook.INF } \\
& \text { 'to have him cooked immediately' }
\end{aligned}
$$

The pattern in (37) follows from Selkirk's hypothesis that clitics are extrametrical syllables, as schematized in (38). If so, apocope takes place cyclically, i.e. from the inner to the outer PrW, targeting the embedded (lexical) word first (e.g. fare $\rightarrow$ far). Once the verb has become C-final, apocope of the outer PrW is blocked because the resulting output would be syllabically illicit. In fact, if both the infinitive and the enclitic underwent apocope, an illicit complex coda would result, e.g. *farl.

\footnotetext{
${ }^{11}$ In certain northern dialects, which underwent degemination, final vowels are normally maintained after etymologically geminate sonorants. Zamboni (1976) pointed out that in modern Venetian, word-final consonants are all etymologically single (e.g. mor < MORIT 'dies'), while vowels are always found after sonorants due to degemination (e.g. core < CURRIT 'runs').
} 


$$
\text { Inner apocope }\{\overbrace{\operatorname{far}(e)}^{\operatorname{PrW}} \overbrace{l^{*}(o)}^{\operatorname{PrW}} \text { Outer apocope }
$$

Furthermore, the above analysis accounts straightforwardly for the cases in which the infinitive is followed by two enclitics. In this case, exemplified in (39), the elements subject to apocope are the infinitive and the outmost clitic:

$$
\begin{aligned}
& \text { Voler_=ve }=l_{-} \quad \text { dir tuto } \quad \text { (Giacomino, Babilonia 89) } \\
& \text { want.INF=you.DAT=it.ACC say all } \\
& \text { 'to want to say it all to you' }
\end{aligned}
$$

According to Peperkamp's analysis of clusters, the representation of the sequence above is as follows:

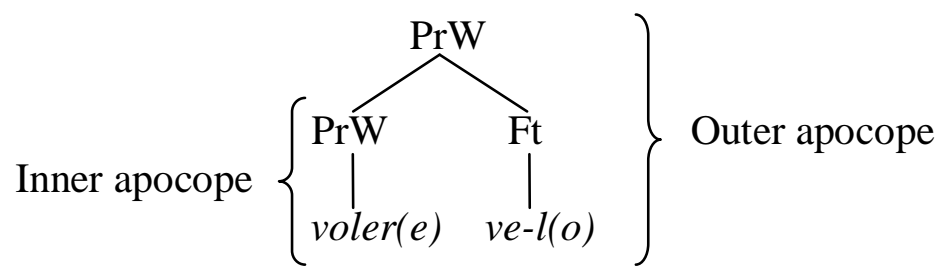

The schema in (40) shows that in this case, outer apocope can take place, as the resulting configuration will not be syllabically illicit: the presence of the 2 pl dative clitic ve prevents the formation of a complex coda and allows the following clitic lo to undergo apocope.

On the contrary, a symmetric analysis à la Nespor \& Vogel (1986), in which each clitic element is a PrW, would be rather problematic as it cannot explain why, among all the possible syllabically licit configurations, only those in (37) and (39) are attested.

\subsection{Alignment constraints}

Many northern vernaculars exhibit another interesting asymmetry: normally, proclitic lo cannot undergo apocope even if it is preceded by a word ending with a vowel, as in (41a) (in the next section, I will account for certain exceptions). Enclitic lo, on the contrary, is free to undergo apocope; see (41b):
en un' aqua lo meto
in a water him.ACC put.3.PL
'they put him in some water'
b. batando=l molto forto
beat.GER=him.ACC very hard
'beating him very hard'
(Giacomino, Babilonia 113)

This asymmetry cannot result from a syllabic principle, since the proclitic $l$ is free to syllabify with the preceding PrW in both (41a) and (41b). The alternative hypothesis is that apocope is blocked because of an alignment constraint, namely a requirement demanding "that a designated edge of each prosodic or morphological constituent [...] coincides with a 
designated edge of some other prosodic or morphological constituent" (McCarthy \& Prince 1993). In a nutshell, if apocope applied, as illustrated in (42a), the clitic $l$ would end up being phonologically enclitic to the preceding word, although it is syntactically proclitic to the following verb, as illustrated in (42b). This would cause a misalignment between the syntactic and the phonological structure, which is the reason why apocope, at least originally, does not target single proclitics.

$$
\text { a. } \quad[\text { en un'aqua }]_{\mathrm{PPh}}[\text { lo meto }]_{\mathrm{PPh}} \quad \rightarrow \quad \text { b. } \quad[\text { en un'aqua } l]_{\mathrm{PPh}}[\text { meto }]_{\mathrm{PPh}}
$$

Interestingly, apocope is not blocked when $l o$ is preceded by another clitic, like a dative clitic pronoun or the negative marker, as in (43):

$$
\begin{aligned}
& v e=l \quad \text { poës cuitar } \\
& \text { you.PL.DAT=it.ACC can.3.SG tell.INF } \\
& \text { 'he can tell it to you' }
\end{aligned}
$$

(Giacomino, Ierusalem 238)

b. cor no ' $l$ po' pensar

(Giacomino, Ierusalem 240)

heart NEG it.ACC can.3SG think.INF

'the heart cannot think it'

In fact, in this context, apocope cannot provoke any misalignment as the presence of a preceding clitic prevents the apocopated clitic $l$ from "falling off" its original PPh when it resyllabifies with the preceding clitic (rather, it is worth noting that clusters are the first context in which apocope is allowed proclitically, cf. (32)).

\subsection{Evidence from prosthesis}

Further support to the misalignment hypothesis is provided by the distribution of clitics exhibiting a prosthetic vowel, e.g. il/el $(<l)$. The diffusion of prosthesis varies across medieval vernaculars and correlates with the diffusion of apocope (Vanelli 1992/1998, see above). In particular, Vanelli shows that prosthetic forms are found in the same phonological context where apocope is allowed, namely V_C. Moreover, she notices that prosthesis is found only in those varieties allowing a wider distribution of apocope, i.e. varieties representative of Stage 2/3.

It is worth noting that, given its distribution in V_C contexts, prosthesis of $l$ cannot be triggered by syllabification principles as $l$ is always free to syllabify with the preceding vowel $^{12}$. Rather, my hypothesis is that prosthesis is a repair strategy that prevented misalignment when apocope began to target clitic elements on the left edge of the $\mathrm{PPh}$.

\footnotetext{
${ }^{12}$ In many modern northern dialects, on the contrary, prosthesis can be regarded as a strategy repairing marked syllabic configurations, which arise as a consequence of vowel deletion processes like apocope. In Gallo-Italic dialects, for instance, apocope determined a systematic loss of final vowels (except $-a$ ) and, consequently, object clitics were reduced to single consonants like $m$ ( $<\mathrm{ME}$, 'me'), $t(<\mathrm{TE}$, 'you.SG'), $l(<\mathrm{ILLUM}$, 'him'), etc. These exponents normally syllabify with either the preceding or the following element. Otherwise, the clitic is syllabified by means of a prosthetic vowel. For instance, in modern Torinese, a prosthetic vowel $a$ is inserted when the object clitic follows the $2^{\text {nd }}$ person subject clitic, which is not expressed by a vocalic exponent: e.g. $* i t$ $m$ ('you to-me') $\rightarrow$ it am (Vanelli 1984, 1998:103).
}

(i) It am das an pum.

(Torinese)

You.cl to-me.cl give an apple

'You give me an apple' 
Take, for instance, a variety like the one of Giacomino da Verona, which - as shown in the previous section - is representative of Stage 2. In fact, in Giacomino's texts, apocope is usually allowed after function words, but not after lexical words. However, there are a few examples in which apocope has exceptionally targeted a single proclitic following a stressed element, as in (44a-c). Crucially, all these counter-examples exhibit prosthesis:

(44) a.

$$
\begin{aligned}
& \text { la scriptura el diso } \\
& \text { the scripture it.ACC says.3PL } \\
& \text { 'so scripture says' }
\end{aligned}
$$

b. li sancti tuti el diso

the saints all it.ACC say.3PL

(Ierusalem 63, 196)

'all the saints say that'

c. enanço k' eli el meta en logo de calura.

(Babilonia 115)

before that they it.ACC put.3PL in place of warm

'before they put him in a hot place'

(Babilonia 34)

In these cases, typical of languages evolving from Stage 2 to Stage 3, apocope applies in a non-canonical context (i.e. when $l o$ is in PPh-initial position), giving rise to the misalignment illustrated in (45b):

(45) a. $\quad[\text { la scriptura }]_{\mathrm{PPh}}[l(o) \text { diso }]_{\mathrm{PPh}} \quad \rightarrow \quad$ b. $\quad[\text { la scriptura }=l]_{\mathrm{PPh}}[\text { diso }]_{\mathrm{PPh}}$ the scripture it.ACC say.3PL

Prosthesis, as a matter of fact, prevents the misalignment by blocking the syllabification of the accusative pronoun with the preceding PrW.

$$
\text { [la scriptura }]_{\mathrm{PPh}} \quad[\text { el diso }]_{\mathrm{PPh}}
$$

This hypothesis is confirmed by the absence of prosthesis in enclisis, illustrated in (47). In this case - see also Loporcaro (1997) - apocope cannot cause any misalignment because the object clitic is on the right edge of its host and, as a consequence, prosthesis is never required.

$$
\begin{aligned}
& \text { Batando }=l \quad \rightarrow \text { batando }=(* e) l \\
& \text { beat.GER }=\text { him.ACC }
\end{aligned}
$$

Second, this accounts for the absence of prosthesis after unstressed elements like negation markers, as schematized in (48) $)^{13}$. Again, in such a context, prosthesis is blocked because $l$ can resyllabify without causing a misalignment.

$$
[\text { no }(* e) l \quad \text { pò }]_{\mathrm{PPh}}
$$

\footnotetext{
${ }^{13}$ One might wonder if the negation marker no is an affixal clitic or a free clitic (cf. (32) vs (33)), as schematised below:
}
(i) $\quad\left[[\text { no l }]_{\mathrm{Ft}}[\text { pò }]_{\mathrm{PrW}}\right]_{\mathrm{PrW}}$
(if no is an affixal clitic)
(ii) $\quad\left[\text { no }\left[1[\mathrm{po}]_{\mathrm{PrW}}\right]_{\mathrm{PrW}}\right]_{\mathrm{PPh}}$
(if no is a free clitic) 
NEG it.ACC can.3SG

'he cannot (do) it'

\section{A vowel alternation in Italian clusters}

In the preceding sections I have supported Peperkamp's claim that clitic clusters are Feet and argued that morpho-phonological processes are sensitive to the alignment of prosodic and syntactic edges. In the light of the preceding analysis, in this section I will take into consideration a context-driven alternation targeting the leftmost clitic of certain Italian clusters. As illustrated in (49), before a $3 \mathrm{p}$ accusative clitic (e.g. lo 'him', la 'her') or the partitive $n e$ ('of it/them'), clitics end with $-e$ instead of $-i$.
[me] lo porti
me.DAT it.ACC bring. $2 \mathrm{SG}$
'You take it to me'
b. $[$ he $]$ ne porti due him.DAT of.it bring.2SG two
'You bring him two of it'
[*mi]
$[* \wedge \mathrm{i}]$

This pattern has received a good deal of attention since D'Ovidio (1886:71), who argues that $e$ - derives from the etymological initial vowel of the second clitic $(e) l o<\operatorname{ILLUM},(e) n e<$ INDE. According to this reconstruction, the derivation of the above clusters goes as follows:
ME ǏLLUM > M'ǏLLU > me lo
'it/him to me'
b. ǏLLI ǏNDE > ILL’ǏNDE > gliene
'of them/it to him/her'

This solution provides a clear and elegant account of the etymology of - $e$ - and its synchronic distribution, since $-e$ - is found only before clitics deriving from ILLE and INDE. However, D'Ovidio's analysis has three major drawbacks.

First, if $-e$ - came from I (< ILLE, INDE), the resulting cluster would be expected to show a geminate sonorant, namely -ll- < ILLE, $-n n-<$ INDE, as illustrated in (51):
a. $\quad$ ME ǏLLUM > M'ǏLLU > *mello
'it/him to me'
b. $\quad$ İLLI ǏNDE > ILL’ ǏNDE > *glienne
'of them/it to him/her'

It is worth noting that in Italian this gemination is shown by sequences of preposition + article (the so-called preposizioni articolate, lit. 'article-d prepositions'), illustrated below (see also Formentin (1996)).
a. DE ǏLLUM > D'ǏLLU > dello
'of the'
b. IN ǏLLUM > (I)N'ǏLLUM > nello
'in the'

In these cases, the preservation of the disyllabic form of the determiner (IILLU > ello) provides a straightforward explanation for both the vowel $-e$ - and the following gemination. In light of 
this, the case of pronoun + pronoun sequences like those in (54) clearly calls for a different explanation, as the absence of gemination is not compatible with D'Ovidio's derivation.

Second, as Parodi $(1887: 189-190)$ pointed out, in the $13^{\text {th }}$ century, the clitics deriving from ILLE, INDE occupied the leftmost position of the cluster and never showed traces of gemination or initial $e$-, as shown by the following examples:
che $[\ldots]$ voi
la $\quad m i \quad$ concediate
that $[\ldots]$ you.PL.NOM it.F.ACC me.DAT grant.SUBJ
'that you grant it to me'
I it.ACC you.PL.DAT tell.FUT
'I will tell it to you'
(Novellino, p.128)

(Boccaccio, Filocolo 212)

b. io lo vi dirò.

The fact that forms like $l o, l a$, ne were originally always in first position weakens D'Ovidio's hypothesis as $-e$ - cannot derive from Ǐ in cluster-internal position.

Third, as shown above, the apocopated allomorph $l(<l o)$ resyllabifies by means of a prosthetic vowel (Vanelli 1992/1998, Renzi 1993, Renzi \& Vanelli 1993). In Florentine, the prosthetic vowel is $i$-, hence $l \rightarrow i l$. Crucially, if the etymological $e$ - $(<\mathrm{I}-)$ had been underlying, the insertion of a prosthetic segment like $i$ - would have been unnecessary.

Alternatively, one might wonder whether the $-e / i$ - alternation is not due to a relic of an etymological segment, but rather to a synchronic pattern of allomorphy exhibited by the leftmost clitic, which has two allomorphs: $\mathrm{mi} / \mathrm{me}$, ti/te, $\mathrm{ci} / \mathrm{ce}$ etc. In what follows, I will elaborate on this proposal in order to account for i) the origin of the allomorphy ii) the synchronic distribution of the $e$-forms.

Rohlfs (1966:178) suggests that the $-e / i$ - alternation originates from a raising process, which, in Old Florentine, turned final unstressed $-e$ into $-i$.

$$
/ \mathrm{e} / \quad \rightarrow \quad[\mathrm{i}] /_{[- \text {-stress }]} \#
$$

This rule targeted adverbs and semi-functional words (e.g. avante > avanti 'before, in front of', diece > dieci 'ten', longe > lungi 'far', etc.) and personal pronouns, giving rise to the alternation between strong pronouns, which maintained the etymological vowel (e.g. Lat. ME $>$ strong $m e$ 'me'), and clitic forms, which underwent raising (e.g. ME > clitic mi).

Arguably, such evolution followed from the change that turned strong pronouns (i.e. XPs corresponding to fully-fledged PrWs) into clitic elements (i.e. $\mathrm{X}^{\circ} \mathrm{s}$ corresponding to bare syllables); see Cardinaletti \& Starke (1999), Egerland (2005). This change, coupled with the rule in (54), led to the alternation between strong $e$-forms (me, $t e, s e$, etc.) on the one hand and clitic $i$-forms ( $m i, t i, c i$, etc.) on the other.
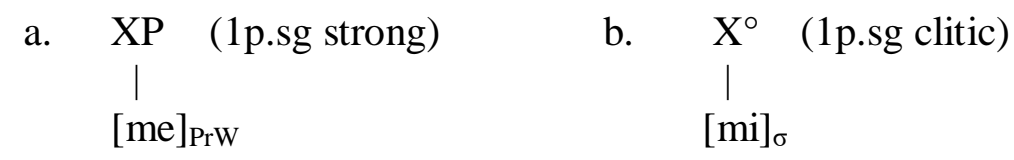

With this in mind, let us turn to the -e/i-alternation in clusters. At first sight, one might argue that, in cluster-initial position, the underlying vowel /e/ surfaces as a consequence of secondary stress, which blocks the rule in (54). This hypothesis, however, does not account straightforwardly for the data.

First, take into consideration the $3 p$ dative clitic gli ('to him') < Lat. ILLI. Since the original ending of the dative clitic is $-i$ (and not $-e$ ), it is expected to show no alternation as its 
underlying form $/ \Lambda \mathrm{i} /$ cannot undergo further raising. In fact, Old Italian was consistent with this prediction since $3^{\text {rd }}$ person dative clitics exhibited the etymological vowel $-i$.

(56) a.

$$
\text { che gli le demo p(er) una inpossta }
$$

(LibrAmm)

that him.DAT them.F.ACC gave.1PL for a tax

'that we gave them to him for a tax'

b. ché gli ne potrebbe troppo di mal seguire (Boccaccio, Dec. because him.DAT of.it could too.much of bad(luck) follow III, 3, p. 197) 'because it could cause him too much misfortune'

Later on, however, the linking vowel of these clusters became - $e_{-}^{-}$, which is the only possible form in modern Italian (I repeat below the relevant example):

$$
\begin{aligned}
& {[\wedge \mathrm{e}] \text { ne porti due }} \\
& \text { him.DAT of.it bring.2SG two } \\
& \text { 'You bring him two of it' }
\end{aligned}
$$

In fact, the linking vowel - $e$ - cannot be the underlying vowel, surfacing as a consequence of foot formation.

Second, contrary to our expectations, the -e/i-alternation is not allowed in several clusters, and in these cases, both clitics display the vowel $-i$ :
a. [mi] ci porta Mario
me.DAT there bring.3SG Mario
'M. brings me there'
[*me]
b. $[$ i $]$ si parla dopo
$[* \wedge \mathrm{e}]$
him.DAT one speak later
'We'll speak to him later'

The situation is summarized in the following table: the first column reports oblique forms in isolation ( $m i, t i, g l i$, etc.), in the second and third columns one can see the same oblique form clustered with the $3 \mathrm{p}$ accusative $l o$ ('him, it') and the partitive ne ('of.it/them'), and in the

\begin{tabular}{|c|c|c|c|c|c|}
\hline & & \multicolumn{2}{|c|}{ with the vowel $-e-$ : } & \multicolumn{2}{|c|}{ with the vowel $-i-$ : } \\
\hline $1 . \mathrm{sg}$ & $(m i)$ & me lo & me ne & mi si & $m i c i$ \\
\hline $\mathrm{sg}$ & $(t i)$ & te lo & te ne & tisi & $t i c i$ \\
\hline 3.sg.dat & (gli) & glielo & gliene & gli si & gli ci \\
\hline
\end{tabular}
fourth and fifth columns the same oblique clitic appears before the $3 p$ reflexive and impersonal clitic si ('himself/herself/themselves/one') and the locative clitic ci ('there').

In order to account for (59) under the phonological analysis (- $e$ - is a consequence of secondary stress), we should postulate at least two classes of clitic clusters: one in which the cluster corresponds to a Foot and the other in which the cluster is formed by a sequence of extrametrical syllables. However, such classification is not supported by any independent piece of phonological evidence.

The alternative explanation is that the $-e / i$ - alternation is syntax-driven, i.e. it is sensitive to the syntactic make-up of the cluster, rather than its prosodic structure. Let us 
assume that the $-e / i$ - alternation is triggered by the presence/absence of a morpho-syntactic edge and that the original rule - rewritten in (60a) - has given rise to the morphological alternation represented in (60b).

(60) a. $\quad / \mathrm{e} / \mathrm{i}] /$

b. $\quad-i / \ldots$

If so, the distribution of $-i$ - in clusters is expected to follow from the presence/absence of a morpho-syntactic boundary (\#), as illustrated by the following scheme:

(61) a. clusters with the vowel -e-, e.g. me lo, me ne, gliene, etc.

b. clusters with the vowel -i-, e.g. mi\#si, mi\#ci, gli\#si, etc.

This amounts to saying that Italian exhibits two types of clitic clusters: one corresponding to a single morpho-syntactic constituent and the other corresponding to a sequence of separate units.

This dichotomy is consistent with Kayne (1994:19-21), who argues that a combination of clitic elements can correspond to two possible structures: a cluster configuration, where one clitic is incorporated onto the other, and a split configuration, where clitics occupy different positions. In the former case, the clitics form a single syntactic unit, while in the latter they are separated by one (or more) maximal projection(s):
a. $\quad[[\mathrm{Cl} 1 \mathrm{Cl} 2] \ldots]$
(cluster)
b. $\quad[\mathrm{Cl} 1 \ldots[\mathrm{Cl} 2 \ldots]]$
(split)

In the reminder of the section, I will argue that the $-e / i$ - alternation correlates with a series of morpho-syntactic phenomena showing that the clusters with the vowel $-i$ - are in fact syntactically split, while the others behave like inseparable syntactic units.

First of all, it is worth noting that all the clusters with the vowel - $e$ - result from a parametric change reversing the order of clitic elements. As previously mentioned, originally the order of those clusters was accusative $>$ dative, as shown in (63a), while the only possible order in Modern Italian ( since the end of the $13^{\text {th }}$ century) is dative $>$ accusative, in (63b).

$$
\begin{aligned}
& \text { che }[\ldots] \text { voi la mi concediate } \\
& \text { that }[\ldots] \text { you.pl it.f to.me grant.subj }
\end{aligned}
$$

(Boccaccio, Filocolo 212)

'that you grant it to me'

b. $\quad$ se Egli me la concede

(Boccaccio, Filocolo 72)

if $\mathrm{He}$ to.me it.f grants

'if He grants it to me'

Melander (1929) noticed that, since the $13^{\text {th }}$ century, the clusters with the innovative order have always exhibited the linking vowel $-e-$, while the clusters with the archaic order always display $-i-$. Building on Kayne, we can argue that the change from (63a) to (63b) is due to the movement and the consequent left-adjunction of the dative clitic onto the accusative one, illustrated in (64), which gives rise to a cluster configuration. 
(64) a. $\quad[\quad l a[m i[\ldots]]]$

b. $\left[\operatorname{me}-l a\left[\mathrm{t}_{m e}\right]\right]$

In the former case, the dative clitic mi occupies a dedicated position and is therefore adjacent to a syntactic boundary. Consequently, the allomorph $-i$ is selected. In (64b), in contrast, the dative clitic is no longer adjacent to the syntactic boundary, as there is no maximal projection intervening between the two clitics. This triggers the insertion of the allomorph $-e$.

Further support comes from synchronic data. Pescarini (2012) shows that split combinations (with $-i-$ ) can be marginally separated in restructuring contexts, as illustrated in (65). On the contrary, the separation is forbidden with true clusters, i.e. with sequences exhibiting the vowel $-e-$, as shown in (66).
a. ${ }^{\%}$ si può portar=ti domani
(cf. ${ }^{\vee}$ ti si può portare...)
one can take=you tomorrow
'we can take you tomorrow'
b. ${ }^{\%}$ mi ha dovuto portar=ci un'amica me has had take=there a friend.F
'A friend of mine had to take me there'
(cf. ${ }^{\vee} m i c i$ ha dovuto portare...)

(66) a. * Carlo si può portar=lo domani
Carlo for.himself can take=it tomorrow
'Carlo can take it for himself tomorrow'

(cf. ${ }^{\vee}$ Carlo se lo può portare...)
b. * lo ha dovuto portar=ci un'amica him/it has had take=there a friend.F
'A friend of mine had to take it/him there'

(cf. ${ }^{\vee}$ ce l'ha dovuto portare...)

This confirms that the $e$-clusters count as a single syntactic constituent, while $i$-sequences are syntactically split, i.e. the clitics occupy different syntactic projections.

In conclusion, in this section I have addressed a morphological alternation targeting the leftmost clitic of certain Italian clusters. Even assuming that the alternation originates from a phonological rule (Rohlfs 1966), I showed that, synchronically, this alternation cannot be due to a morpho-phonological process triggered by secondary stress. Rather, I argued for a syntactic analysis on the basis of Kayne's hypothesis that clitic combinations can be either clusters or split sequences. Building on independent syntactic evidence, I showed that the vowel $-i$ - appears when a clitic is in a split configuration, while $-e$ - is the linking vowel of clitics forming a true cluster.

\section{Conclusions}

In this paper I have investigated some morpho-phonological aspects of clitic clusters on the basis of data from modern and medieval (Italo)Romance.

First of all, I have argued against Nespor \& Vogel's account of the prosodic status of clitics by claiming that intervocalic $s$-voicing, raddoppiamento sintattico and apocope do not support a symmetric prosodic model based on exhaustive and non-recursive hierarchies. 
On the contrary, evidence for an asymmetric account comes from the analysis of clitic clusters in southern Italian dialects like Neapolitan (Bafile 1992, 1994, Peperkamp 1995, 1996, 1997) and Old French (Horne 1990). These phenomena show that clitic clusters must be conceived of as Feet that are daughters to a recursive PrW, as illustrated below:

\section{[ (clitic.clitic) [ lexical word $\left.]_{\mathrm{PrW}}\right]_{\mathrm{PrW}}$}

In light of this analysis I have addressed the distribution of apocope in medieval ItaloRomance; I have argued that the distribution of the apocopated clitic $l(<l o)$ depends on syllabic and alignment conditions constraining its re-syllabification.

A syllabic condition blocks apocope if the resulting $l$ ends up forming a complex coda. In particular, the syllabic constraint provides a straightforward account of the distribution of apocope in sequences formed by an infinitive and one or two clitic pronoun(s). In this case, the correct distribution results from a recursive application of apocope, as schematized below:
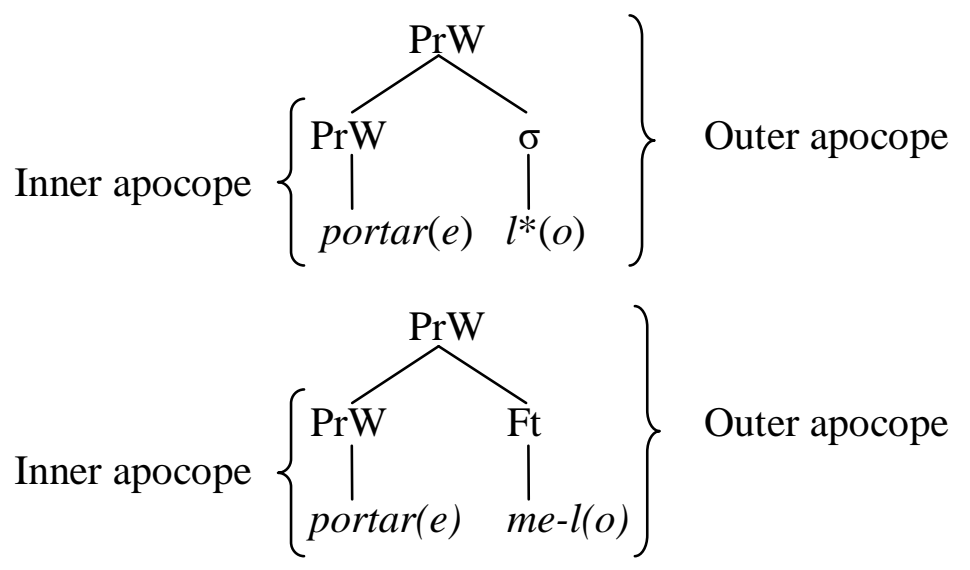

The alignment constraint accounts for the fact that clitics on the left edge of a $\mathrm{PPh}$ are not subject to apocope. I have argued that apocope is blocked in order to prevent $l$ from syllabifying with the preceding $\mathrm{PPh}$, causing a syntax/prosody misalignment. Otherwise, if apocope targets a proclitic element, a prosthetic vowel is inserted to avoid the syntax/prosody misalignment.

Lastly, I have addressed a puzzling alternation exhibited by the linking vowel of Italian clusters. After an in-depth revision of previous analyses, I have argued that this allomorphy is sensitive to the syntactic make-up of the cluster rather than to its prosodic structure.

\section{References}

Bafile, Laura. 1992. Fonologia prosodica e teoria metrica: accento, cliticizzazione e innalzamento vocalico in napoletano. $\mathrm{PhD}$ dissertation, Università di Firenze.

Bafile, Laura. 1994. La riassegnazione postlessicale dell'accento del napoletano. Quaderni del Dipartimento di Linguistica - Università di Firenze 5: 1-23.

Benincà, Paola. 2008. Grammatica e stili dell'italiano. In Didattica della lingua italiana: testo e contesto, A. Ledgeway \& A.L. Lepschy (eds.), 73-84. Perugia: Guerra.

Cardinaletti, Anna. 2008. On different types of clitic clusters. In The Bantu-Romance Connection, Cécile De Cat \& Katherine Demuth (eds.), 41-82. Amsterdam: Benjamins. 
Cardinaletti, Anna \& Lori Repetti. 2008. The Phonology and Syntax of Preverbal and Postverbal Subject Clitics in Northern Italian Dialects. Linguistic Inquiry 39(4): 523563.

Cardinaletti, Anna \& Ur Shlonsky. 2004. Clitic Positions and Restructuring in Italian. Linguistic Inquiry 35(4): 519-557.

Cardinaletti, Anna \& Michal Starke. 1999. The typology of structural deficiency: A case study of the three classes of pronouns. In Clitics in the languages of Europe, H. van Riemsdijk (ed.), 145-233. Berlin and New York: De Gruyter.

D'Ovidio, Francesco. 1886. Ricerche sui pronomi personali e possessivi neolatini. Archivio Glottologico Italiano 9: 25-101.

Egerland, Verner. 2005. Diachronic change and pronoun status: Italian dative 'loro'. Linguistics 43: 1105-1130.

Formentin, Vittorio. 1996. Alcune considerazioni e un'ipotesi sull'articolo determinativo in area romanza. In Studi offerti a Luigi Blasucci dai colleghi e dagli allievi pisani, L. Lugnani, M. Santagata \& A. Stussi (eds.), 275-272. Lucca: Maria Pacini Fazzi editore.

Harris, James. 1991a. The Exponence of Gender in Spanish. Linguistic Inquiry 22(1): 27-62.

Harris, James. 1991b. The Form Classes of Spanish Substantives. Yearbook of Morphology 1: 65-88.

Horne, Merle. 1990. The clitic group as a prosodic category in old French. Lingua 82(1): 113.

Kayne, Richard. 1994. The Antisymmetry of Syntax. Cambridge MA: MIT Press.

Krämer, Martin. 2009. The Phonology of Italian. Oxford: Oxford University Press.

Loporcaro, Michele. 1997. On Vowel epenthesis in Alguer Catalan. In Certamen Phonologicum III, P.M Bertinetto, L. Gaeta, G.J. Jatchev, D. Michaels (eds.), 205-227. Torino: Rosemberg \& Sellier.

McCarthy John J. \& Alan S. Prince. 1993. Generalized alignment. Yearbook of Morphology 1993: 79-154. Also in Rutgers Optimality Archive 7: 〈http://roa.rutgers.edu>

Melander, Johan. 1929. L'origine de l'Italien me ne, me lo, te la, etc. Studia Neophilologica 2: 169-203.

Monachesi, Paola. 1996. On the representation of Italian clitics In Interfaces in Phonology [Studia Grammatica 41], U. Kleinhenz (ed.), 83-101. Berlin: Akademie Verlag.

Nespor, Marina. 1990. Vowel deletion in Italian. The organization of the phonological component. The Linguistic Review 7, 375-398.

Nespor, Marina. 1993. Fonologia. Bologna: Il Mulino.

Nespor, Marina \& Irene Vogel. 1986. Prosodic phonology. Dordrecht: Foris Publications.

Oostendorp, Marc van. 1999. Italian s-voicing and the structure of the phonological word. In Issues in Phonological Structure, S.J. Hannahs and Mike Davenport (eds.), 197-214. Amsterdam: Benjamins.

Parodi, Ernesto Giacomo. 1887. Illustrazioni linguistiche ai suddetti frammenti. Giornale storco della letteratura italiana 10. 178-196.

Peperkamp, Sharon. 1995. Enclitic stress in Romance. In Papers from the 31st Regional Meeting of the Chicago Linguistic Society, Volume 2: The Parasession on Clitics, A. Dainora, R. Hemphill, B. Luka, B. Need \& S. Pargman (eds.), 234-249. Chicago: Chicago Linguistic Society.

Peperkamp, Sharon. 1996. On the Prosodic Representation of Clitics. In Interfaces in Phonology [Studia Grammatica 41], U. Kleinhenz (ed.), 102-127. Berlin: Akademie Verlag.

Peperkamp, Sharon. 1997. Prosodic Words [HIL dissertations 34]. The Hague: Holland Academic Graphics. 
Pescarini, Diego. 2011. The evolution of Lat. ILLUM in Old Veronese: apocope and related phenomena. Vox Romanica 70: 63-78.

Pescarini, Diego. 2012. Prosodic restructuring and morphological opacity. The evolution of Italo-Romance clitic clusters. Lingbuzz/001477

Renzi, Lorenzo. 1993. Da dove viene l'articolo il. In Verbum Romanicum, Festschrift für Maria Iliescu, J. Kramer \& G.A. Plangg (eds.), 215-230. Hamburg: Buske.

Renzi, Lorenzo \& Laura Vanelli. 1993. Storia e struttura dell'articolo italiano il. In Actes du XX $X^{e}$ Congrès International de Linguistique et Philologie Romanes, III, 293-305. Tübingen, Francke Verlag.

Rohlfs, Gerhard. 1966. Grammatica storica della lingua italiana e dei suoi dialetti. Vol. I: Fonetica. Turin: Einaudi.

Selkirk, Elisabeth. 1995. The prosodic structure of function words. In Papers in Optimality Theory, Jill Beckman, Laura Walsh Dickey, \& Suzanne Urbanczyk (eds.), 439-70. Amherst, MA: GLSA Publications. Also in Signal to Syntax: Bootstrapping from Speech to Grammar in Early Acquisition, James L. Morgan \& Katherine Demuth (eds.), 187-214. Mahwah NJ: Lawrence Erlbaum Associates.

Vanelli, Laura. 1984. Pronomi e fenomeni di prostesi vocalica nei dialetti italiani settentrionali. Revue del linguistique romane 48: 281-295

Vanelli, Laura. 1992. Da "lo" a "ill": storia dell'articolo definito maschile singolare in italiano e nei dialetti settentrionali. Rivista Italiana di Dialettologia 16: 29-66.

Vanelli, Laura. 1998. I dialetti italiani settentrionali nel panorama romanzo. Roma: Bulzoni.

Zamboni, Alberto. 1976. Alcune osservazioni sull'evoluzione delle geminate romanze. In Studi di fonetica e fonologia, R. Simone, U. Vignuzzi \& G. Ruggiero (eds.), 325-336. Roma, Bulzoni.

\section{Texts:}

Boccaccio, Decameron = Giovanni Boccaccio, Decameron, ed. by Vittore Branca, Firenze, Accademia della Crusca, 1976.

Boccaccio, Filocolo = Giovanni Boccaccio, Filocolo ed. by Antonio Enzo Quaglio, in Tutte le opere di Giovanni Boccaccio, vol. I, Milan, Mondadori, 1967, 61-675.

Dante, Inf = Dante Alighieri, Commedia, ed. by Giorgio Petrocchi, vol. II Inferno

Giacomino, Ierusalem/Babilonia. = Giacomino da Verona, De Ierusalem Celesti e De Babilonia civitate infernali, ed. by G. Contini, Poeti del Duecento, tomo I, Napoli, 1950, 627-652.

Guittone, Rime, = Guittone d'Arezzo, Rime ed. by Francesco Egidi, Bari, Laterza, 1940.

LibrAmm = Anonymous, Libro d'amministrazione dell'eredità di Baldovino Iacopi Riccomanni, in Arrigo Castellani, La prosa italiana delle origini: I, Testi toscani di carattere pratico, Bologna, Pàtron, 1982, 429-64

LibrCred = Anonymous, Libricciolo di crediti di Bene Bencivenni (Secondo), in Arrigo Castellani, Nuovi testi fiorentini del Dugento, Firenze, Sansoni, 1952, 363-458.

Novellino = Anonymous, Il Novellino, ed. by Guido Favati, Genova, Bozzi, 1970. 